\title{
EXPERIMENTS ON THE EXTRACTION OF POTASH FROM WYOMINGITE.
}

\author{
By Roger C. Wells.
}

\section{INTRODUCTION.}

The United States Geological Survey has now made a considerable number of explorations in search of a domestic source of potash and further explorations are under way. In the meantime the Survey has studied the chemical and physical characteristics of the rocks, minerals, and salines so far discovered, and it is the object of the present paper to describe laboratory experiments made with the rock wyomingite.

Wyomingite, a lava occurring extensively in the Leucite Hills in Sweetwater County, Wyo., ${ }^{1}$ is composed largely of the mineral leucite, a silicate of alumina and potash. Leucite is far richer in potash than feldspar, which is commonly regarded as one of the most promising prospective sources of potash. Moreover, the potash in leucite, although not soluble in water, seems to be more easily attackable by reagents than that in feldspar, so that if any igneous rock should become a source of potash wyomingite would have advantages over a feldspar-bearing rock. Data on the properties of wyomingite will therefore be valuable. While all the experiments to be described here can not be considered as suggestions of commercial possibilities, a record of them may not only be suggestive to private investigators, but save much repetition of preliminary investigation.

\section{CHEMICAL COMPOSITION OF WYOMINGITE.}

The wyomingite used in the experiments to be described has the following composition:

1 The quantity of leucite-bearing rock present at this locality is estimated at nearly 2,000,000,000 tons, containing an average of 10 per cent of potash. See U. S. Geol. Survey Bull. 512, p. 35, 1912.
Composition of wyomingite. ${ }^{2}$

[W. F. Hillebrand, analyst.]

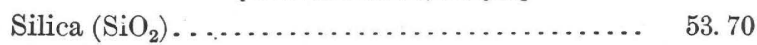

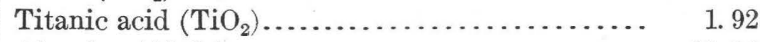

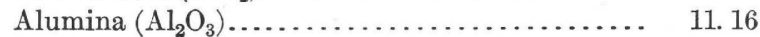

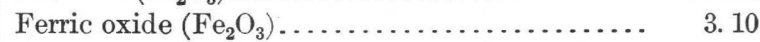

Ferrous oxide $(\mathrm{FeO}) \ldots \ldots \ldots \ldots \ldots \ldots \ldots \ldots \ldots \ldots \ldots \ldots \ldots, 1.21$

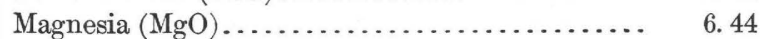

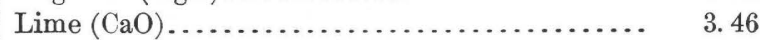

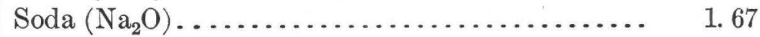

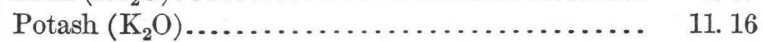

Water $\left(\mathrm{H}_{2} \mathrm{O}\right) \ldots \ldots \ldots \ldots \ldots \ldots \ldots \ldots \ldots \ldots \ldots \ldots \ldots \ldots \ldots \ldots, \quad 3.41$

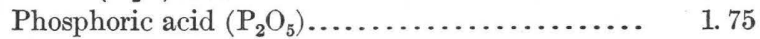

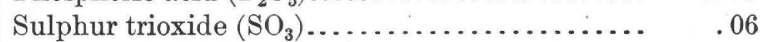

Fluorine $(\mathrm{F}) \ldots \ldots \ldots \ldots \ldots \ldots \ldots \ldots \ldots \ldots \ldots \ldots \ldots \ldots \ldots \ldots, \quad .44$

Other constituents....................... .92

Specific gravity, 2.627.

100.40

This rock was obtained near Fifteen-mile Spring, on the northeast side of Zirkel Mesa. It is the typical dense reddish-brown wyomingite, such as occurs in many of the mesas and hills of this region.

\section{MINERAL COMPOSITION OF WYOMINGITE.}

According to Cross $^{3}$ this wyomingite really consists of the following minerals: Uncombined silica, 22.5 per cent; leucite, 35.7 per cent; phlogopite, 22.3 per cent; diopside, 10.7 per cent; and accessory minerals, 8.8 per cent. The potash content of wyomingite is distributed among leucite, phlogopite, and a glassy base which is chiefly uncombined silica. There is enough uncombined silica in wyomingite to have formed a feldspar, and why leucite was formed instead has not yet been explained.

2 Clarke, F. W., Analyses of rocks and minerals from the laboratory of the United States Geological Survey, 1880-1914: U. S. Geol. Survey Bull. 591, p. 74, 1915.

${ }^{3}$ Cross, Whitman, Igneous rocks of the Leucite Hills and Pilot Butte, Wyo.: Am. Jour. Sci., 4th ser., vol. 4, p. 133, 1897. 
On the assumption that in any process of extraction this silica can be kept from combining with the potash, the advantage inherent in the wyomingite can be seen at a glance by comparing the theoretical percentage of potash in leucite with that in orthoclase feldspar, leucite $\left(\mathrm{K}_{2} \mathrm{O} \cdot \mathrm{Al}_{2} \mathrm{O}_{3} \cdot 4 \mathrm{SiO}_{2}\right)$ containing 21.5 per cent and orthoclase $\left(\mathrm{K}_{2} \mathrm{O} \cdot \mathrm{Al}_{2} \mathrm{O}_{3} \cdot 6 \mathrm{SiO}_{2}\right) 16.9$ per cent.

\section{BEHAVIOR OF CRUSHED WYOMINGITE IN WATER.}

As leucite has a specific gravity of 2.45 to 2.50 , while the specific gravities of phlogopite, diopside, and silica are 2.7, 3.3, and 2.6, respectively, it was hoped that some separation of the lighter and more valuable mineral could be made by a flotation process. A small amount of wyomingite was crushed to pass an 80-mesh screen and separated into two portions, one heavier and one lighter, by panning with water. Each of these portions was panned similarly. The combined lighter portions weighed 0.93 gram and the heavier portions 0.60 gram. The lighter portion was analyzed with the following results:

Effect of panning wyomingite.

\begin{tabular}{|c|c|c|}
\hline & $\begin{array}{c}\text { Original } \\
\text { rock. }\end{array}$ & $\begin{array}{c}\text { Lighter } \\
\text { por- } \\
\text { tion. }\end{array}$ \\
\hline $\begin{array}{l}\mathrm{K}_{2} \mathrm{O} \\
\mathrm{N}_{2} \mathrm{O}\end{array}$ & $\begin{array}{r}11.2 \\
1.7\end{array}$ & $\begin{array}{rl}12.1 & \\
1.1 & 0\end{array}$ \\
\hline
\end{tabular}

Although the effect was not as great as desired it is evident that the method of concentration used caused some separation of the leucite from the other minerals. According to Cross, wyomingite is a very fine grained rock, so that it may be too much to expect that a mechanical method of concentration will effect a complete separation, but if such a method could be discovered, it would render an enormous quantity of mineral having a high potash content available for chemical treatment.

Cold water attacks leucite somewhat, but the action is so slight that the fact has scarcely any significance unless it is in agricultural chemistry. When certain other salts are present in the water, however, the action is somewhat more noticeable. This was shown by some experiments carried out with wyomingite and gypsum, 10 grams of each, powdered, being placed in 500 cubic centimeters of water. After shaking one day it was found that 0.0035 gram of $\mathrm{K}_{2} \mathrm{O}$, or 0.31 per cent of the total $\mathrm{K}_{2} \mathrm{O}$ in the rock, had been extracted by the solution. A week later the potash in solution was found to be 0.61 per cent of the total $\mathrm{K}_{2} \mathrm{O}$ originally in the rock. These facts are also of interest in relation to agricultural or soil chemistry and are probably to be explained as due to a metathetical reaction by which a part of the calcium of the gypsum in the solution exchanges itself for the potassium in the leucite.

In order to see if this exchange could be brought about to a greater extent by grinding the constituents 10 grams each of wyomingite and gypsum were ground with 50 cubic centimeters of water in an agate mortar by a mechanical grinder for two hours. The resulting solution, after filtration, was found to contain 2 per cent of all the potash $\left(\mathrm{K}_{2} \mathrm{O}\right)$ in soluble form. This is, however, only 0.22 per cent of the rock.

An experiment similar to the last was carried out with lime in place of gypsum, resulting in the extraction of 2.64 per cent of the potash in soluble form, or 0.34 per cent of the rock.

\section{EFFECT OF HEATING WYOMINGITE.}

Merely heating wyomingite to a dull red apparently causes very little change in it. After it is heated a trace of its potash is found to be soluble in water, but this fact can have no commercial significance. For effective action some reagent must be added. The following notes describe the effect of heating mixtures of the rock and certain reagents:

\section{EXPERIMENTS WITH GYPSUM.}

In addition to the experiments with gypsum already described, the following were made:

1. A mixture of 1 gram of wyomingite and 0.2 gram of gypsum was finely ground and ignited until fused. After cooling it was ground and extracted with water. The soluble $\mathrm{K}_{2} \mathrm{O}$ amounted to 1.8 per cent of the rock, or 16.2 per cent of the total $\mathrm{K}_{2} \mathrm{O}$.

2. A mixture of 1 gram of wyomingite, 0.22 gram of gypsum, and 0.10 gram of sodium chloride was finely ground, ignited to a dull red, and, after cooling, extracted with water. The soluble $\mathrm{K}_{2} \mathrm{O}$ amounted to 2.5 per cent of the rock, or 22.4 per cent of the total $\mathrm{K}_{2} \mathrm{O}$.

In the light of these results gypsum does not appear to be very efficient in decomposing the 
rock, at least when used in the proportions tried in these experiments.

\section{EXPERIMENTS WITH SULPHURIC ACID.}

1. One gram of wyomingite was moistened with 1 cubic centimeter of concentrated sulphuric acid and heated gently in a large platinum crucible for about an hour until fumes came off freely. The soluble $\mathrm{K}_{2} \mathrm{O}$ extracted amounted to 2.72 per cent of the rock, or 24.5 per cent of the total $\mathrm{K}_{2} \mathrm{O}$.

2. One gram of wyomingite was ground with 0.22 gram of gypsum, moistened with dilute sulphuric acid equivalent to 0.18 gram $\mathrm{H}_{2} \mathrm{SO}_{4}$, dried, and heated to redness. The soluble $\mathrm{K}_{2} \mathrm{O}$ extracted amounted to 2.75 per cent of the rock, or 24.8 per cent of the total $\mathrm{K}_{2} \mathrm{O}$.

\section{EXPERIMENT WITH POTASSIUM BISULPHATE.}

On the theory that the action of hot sulphuric acid on wyomingite produces some potassium bisulphate, an experiment was made with potassium bisulphate itself as a reagent. One gram of wyomingite was finely ground with 0.5 gram of potassium bisulphate, and the mixture was brought up slowly to a dull-red heat. The result was disappointing. Hardly any more $\mathrm{K}_{2} \mathrm{O}$ was extracted than had been added in the reagent, though nearly all the $\mathrm{Na}_{2} \mathrm{O}$ of the wyomingite had been converted into a soluble form.

This experiment seems to indicate that the rearrangement effected in the sintering is governed by the law of mass action, and that treatment with a potassium reagent is not likely to be efficient, at least for a commercial process.

\section{EXPERIMENTS WITH ALUNITE.}

Notwithstanding the unfavorable result of the last experiment it seemed worth while to try the effect of heating wyomingite and alunite together. Alunite is to be found comparatively near the Leucite Hills, and the idea of the experiment was that a combination of the two rocks might be treated in a single process at a lower cost than the combined cost of treating each separately. The alunite used came from Marysvale, Utah, and was part of that analyzed by W. T. Schaller for Butler and Gale, ${ }^{1}$ who described the deposit in 1912.

\footnotetext{
${ }^{1}$ Butler, B. S., and Gale, H. S., Alunite, a newly discovered deposit near Marysvale, Utah: U. S. Geol. Survey Bull. 511, 1912.
}

Composition of alunite.

[W. T. Schaller, analyst.]

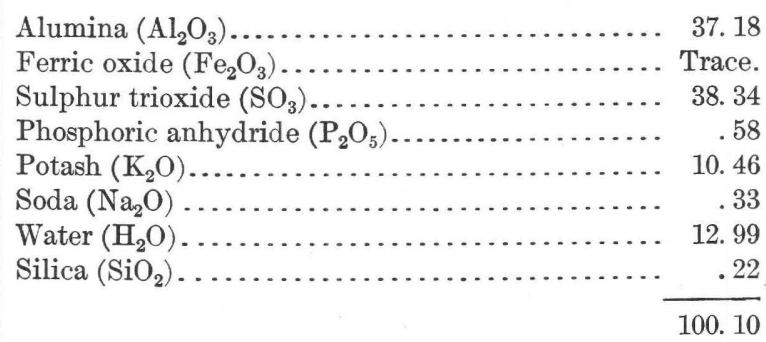

1. Wyomingite (0.2 gram) was finely ground with 0.2 gram of alunite. After being slowly heated to a dull red and then held at a medium red for an hour in a J. Lawrence Smith platinum crucible the cooled lump was extracted with water and yielded soluble $\mathrm{K}_{2} \mathrm{O}$ equivalent to 6.15 per cent of the mixture. As the theoretical yield of $\mathrm{K}_{2} \mathrm{O}$ would be 5 per cent from the alunite and 5.5 per cent from the wyomingite, a total of 10.5 per cent, the amount actually extracted was 57 per cent of the total $\mathrm{K}_{2} \mathrm{O}$-that is, the $\mathrm{K}_{2} \mathrm{O}$ extracted might be considered all that in the alunite alone plus about 20 per cent of that in the wyomingite. As there is a very large quantity of wyomingite available and as the cost of mining and crushing would doubtless be low, it would appear that when alunite is being treated the addition of wyomingite might pay.

2. The next experiments consisted in varying the proportions of alunite and wyomingite. By taking 0.2 gram of alunite and 0.4 gram of wyomingite, the soluble $\mathrm{K}_{2} \mathrm{O}$ obtained amounted to 7.6 per cent of the mixture. The theoretical yield of $\mathrm{K}_{2} \mathrm{O}$ would be 3.5 per cent from the alunite and 7.4 per cent from the wyomingite, a total of 10.9 per cent; the $\mathrm{K}_{2} \mathrm{O}$ extracted therefore amounted to 70 per cent of the total-that is, all the potash in the alunite was extracted and 55 per cent of that in the wyomingite.

3. In another experiment with 0.2 gram of alunite and 0.6 gram of wyomingite the yield in soluble $\mathrm{K}_{2} \mathrm{O}$ was 3 per cent of the mixture. As the theoretical yield would be 2.6 per cent from the alunite and 8.2 per cent from the wyomingite, or 10.8 per cent in all, the result represents only 28 per cent of the total $\mathrm{K}_{2} \mathrm{O}$. In this experiment the wyomingite was only slightly attacked. 


\section{EXPERIMENT WITH CALCIUM CARBONATE.}

The well-known method devised by J. Lawrence Smith for determining the alkalies in silicate rocks, involving the use of calcium carbonate and ammonium chloride, probably owes its success to the action of calcium chloride formed during the reaction. However that may be, the proportions of the reagents used in this method are too great to be practicable for commercial process, and accordingly it seemed desirable to make a few experiments to see if the proportions of the reagents could be reduced. One experiment was tried out with calcium carbonate alone, 0.3 gram of calcium carbonate to 1 gram of wyomingite being used. At the temperature employed, a dull-red heat, scarcely more than a trace of potash was rendered soluble. This result seemed to show that the chief attack in the Smith method is due to the calcium chloride, and accordingly the next experiments were made with calcium chloride alone.

\section{EXPERIMENTS WITH CALCIUM CHLORIDE.}

It was found that with moderate proportions of calcium chloride too high a heat, say $1,000^{\circ}$ C., causes the mixture to vitrify so that extraction of the potash by water is impracticable. The temperature used was therefore limited to a dull-red heat. The calcium chloride was added in solution to finely ground wyomingite in a platinum crucible, and the mixture was slowly stirred during evaporation until the mass was dry.

The results of the experiments are summarized below:

Potash rendered soluble when wyomingite is heated to a dull red with calcium chloride.

\begin{tabular}{|c|c|c|c|}
\hline \multirow{2}{*}{$\begin{array}{c}\text { Wyoming- } \\
\text { ite. }\end{array}$} & \multirow[b]{2}{*}{$\mathrm{CaCl}_{2}$. } & \multicolumn{2}{|c|}{$\begin{array}{c}\mathrm{K}_{2} \mathrm{O} \text { rendered } \\
\text { soluble. }\end{array}$} \\
\hline & & $\begin{array}{l}\text { Percent- } \\
\text { age of } \\
\text { rock. }\end{array}$ & $\begin{array}{c}\text { Percent- } \\
\text { age of } \\
\text { total } \\
\mathrm{K}_{2} \mathrm{O} \text {. }\end{array}$ \\
\hline $\begin{array}{r}\text { Gram. }_{1} \\
1 \\
1\end{array}$ & $\begin{array}{r}\text { Gram. } \\
0.2 \\
.4 \\
.6\end{array}$ & $\begin{array}{l}3.03 \\
6.44 \\
8.10\end{array}$ & $\begin{array}{l}27.3 \\
58.0 \\
73.0\end{array}$ \\
\hline
\end{tabular}

\section{EXPERIMENT WITH MAGNESIUM CHLORIDE.}

One gram of powdered wyomingite was moistened with a saturated solution of magnesium chloride, dried, and heated slowly to dull redness in an open crucible. On extraction the soluble $\mathrm{K}_{2} \mathrm{O}$ amounted to 3.22 per cent of the rock, or 29 per cent of the total $\mathrm{K}_{2} \mathrm{O}$ in the rock.

\section{EXPERIMENT WITH A BITTERN.}

When it was found that a part of the alkalies in wyomingite is rendered soluble by heating with magnesium chloride, an experiment was made with a bittern, such as is obtained in the manufacture of salt at Great Salt Lake, having the composition shown below:

Composition of bittern used.

\begin{tabular}{|c|c|c|}
\hline & $\begin{array}{c}\text { Grams per } \\
\text { liter. }\end{array}$ & $\begin{array}{l}\text { Per cent } \\
\text { of salts. }\end{array}$ \\
\hline \multirow[t]{2}{*}{ 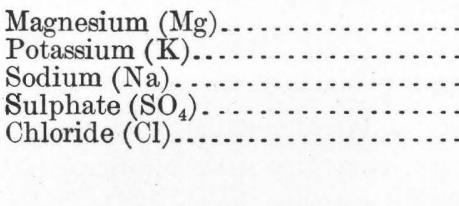 } & $\begin{array}{r}24.9 \\
15.9 \\
69.3 \\
65.0 \\
145.9\end{array}$ & $\begin{array}{r}7.76 \\
4.94 \\
21.60 \\
20.27 \\
45.43\end{array}$ \\
\hline & 321.0 & 100.00 \\
\hline
\end{tabular}

One gram of wyomingite was drenched with 2 cubic centimeters of the bittern, dried, and heated to dull redness, with the following results: Soluble $\mathrm{K}_{2} \mathrm{O}, 5.32$ per cent of the dry mixture; theoretical yield of $\mathrm{K}_{2} \mathrm{O}, 2.3$ per cent from the bittern and 6.8 per cent from the wyomingite, or 9.1 per cent in all; $\mathrm{K}_{2} \mathrm{O}$ extracted, 58 per cent of total $\mathrm{K}_{2} \mathrm{O}$. The $\mathrm{K}_{2} \mathrm{O}$ extracted may be considered to be all that of the bittern used and 44 per cent of that in the wyomingite.

\section{EXPERIMENT WITH AMMONIUM SULPHATE.}

Ammonium chloride in excess and under pressure is known to react with leucite at $350^{\circ}$ in such a way as to set potassium chloride free. ${ }^{1}$ It seemed worth while to try ammonium sulphate also. In a single experiment 1 gram of wyomingite was heated over night in a closed glass tube at $310^{\circ}$ with 0.2 gram of ammonium sulphate. The potash rendered soluble by this treatment amounted to 0.0352 gram, or 31.8 per cent of the total potash in the rock.

1 Clarke, F. W., and Steiger, George, The action of ammonium chloride upon silicates: U. S. Geol. Survey Bull. 207, p. 16, 1902. 